\title{
Risk Analysis of Occupational Diseases in
}

\section{Harbor Community}

\author{
Tri Martiana \\ Department of Occupational Safety and Health \\ Universitas Airlangga \\ Surabaya \\ Tri.martiana@fkm.unair.ac.id
}

\begin{abstract}
Harbor workers have risk of being affected by hazards that possibly develop into occupational diseases. The objective of this research was to describe hazards that could possibly develop into occupational diseases in harbor community. This research used a cross-sectional approach and descriptive method. The sample was 94 respondents in work areas of Kantor Kesehatan Pelabuhan (KKP), Kelas I, Surabaya, and was selected with random sampling technique. The instrument used was questionnaire. Data analysis was performed with descriptive technique. Potential hazards that could cause occupational diseases were workplace temperature, noise and poor lighting, while noncompliance with PPE protocols could increase the risk of hazard exposure. Control over potential hazards should be performed and compliance with PPE protocols should be improved.
\end{abstract}

Keywords- Hazard identification; harbor community; exposure;

\section{INTRODUCTION}

Harbor community is a group of people who have work activities related to transportation in a harbor environment. The environment covers buffer area and perimeter area. The people are those who stay in a harbor for work or a visit and those who live there. A harbor is a point where ships, goods and people meet and also a potential place of disease dissemination. ${ }^{[1]}$ People who work in harbors, such as ship crews, health workers, longshoremen and others have risk of hazard exposure that may cause occupational injuries and diseases. They have high risk of physical, chemical, biological and psychological hazard exposure. ${ }^{[2]}$ All kinds of workplace hazard should be controlled to prevent occupational injuries and diseases. ${ }^{[3]}$

According to the International Labour Organization (ILO), workplace death cases are caused by cancer $(34 \%)$, workplace injuries $(25 \%)$, respiratory diseases $(21 \%)$, cardiovascular diseases $(15 \%)$ and other factors $(5 \%){ }^{[4]}$ Occupational injury prevention can be planned, performed and controlled by conducting a characteristics study of injuries so that prevention and control can be

\author{
Noeroel Widajati \\ Department of Occupational Safety and Health \\ Universitas Airlangga \\ Surabaya \\ Noeroel.widajati@fkm.unair.ac.id
}

performed with the right approach. Risk analysis of occupational diseases was conducted with an occupational epidemiology approach. Analysis was done to the three main factors of host (human factor), agent (noise, dust exposure, lighting levels), and environment (workplace temperature). These three factors could promote occupational disease risk. The objective of this research was to describe hazards that could possibly develop into occupational diseases in harbor community.

\section{METHODS}

This research was observational research with a cross-sectional approach. A survey of occupational health and safety conditions was conducted to harbor community in work areas of Kantor Kesehatan Pelabuhan (KKP), Kelas I, Surabaya. The sample was 94 respondents consisting of ship crews and employees of KKP, Kelas 1, Surabaya. The sample was selected with random sampling.

Dependent variable of this research was occupational diseases, while independent variables covered host (PPE compliance), agent (noise, dust exposure, lighting levels) and environment (workplace temperature).

Primary data collection was performed with observation guide and questionnaire. Lab examination was also conducted to complete the primary data. It covered lung capacity measurement with autospirometer and hearing acuity measurement with audiometer. Data analysis was performed descriptively and used computer software.

\section{RESULT}

a. Result of workplace environment identification in harbor work area.

Kantor Kesehatan Pelabuhan (KKP), Kelas I, Surabaya, has work areas covering Tanjung Perak Surabaya port, Juanda port, Gresik port, Tuban port and Kalianget port. Workers with high intensity of working in harbor were ship 
crews and KKP employees whose job was examining ships. During working activities, there were some potential hazards that could cause occupational diseases. Those hazards were extreme temperature, dust exposure, noise and non-compliance with PPE.

Table 1 Result of hazards identification

\begin{tabular}{|c|c|c|c|c|c|}
\hline $\begin{array}{l}\mathrm{N} \\
\mathrm{o}\end{array}$ & $\begin{array}{l}\text { Measurement } \\
\text { Location }\end{array}$ & $\begin{array}{c}\text { WBGT } \\
\left({ }^{\circ} \mathrm{C}\right)\end{array}$ & $\begin{array}{c}\text { Average } \\
\text { Noise } \\
\text { Level } \\
\text { (dBA) }\end{array}$ & $\begin{array}{c}\text { Noise } \\
\text { Categ } \\
\text { ories }\end{array}$ & $\begin{array}{c}\text { Illumina } \\
\text { nce } \\
\text { (Lux) }\end{array}$ \\
\hline \multicolumn{6}{|c|}{ KM Hijau Jelita } \\
\hline & \begin{tabular}{|ll} 
a. & $\begin{array}{l}\text { Engine } \\
\text { room }\end{array}$ \\
\end{tabular} & 29.0 & 90 & Loud & 120 \\
\hline & b. $\quad$ Office & 22.1 & 53.4 & $\begin{array}{l}\text { Not } \\
\text { loud }\end{array}$ & 375 \\
\hline & c. Kitchen & 26.9 & 70.6 & $\begin{array}{l}\text { Not } \\
\text { loud }\end{array}$ & 75 \\
\hline \multirow[t]{4}{*}{2} & \multicolumn{5}{|c|}{ KM Thimoty } \\
\hline & a. Engine room & 28.9 & 65.2 & $\begin{array}{l}\text { Not } \\
\text { loud }\end{array}$ & 40 \\
\hline & b. Office & 28.1 & 57 & $\begin{array}{l}\text { Not } \\
\text { loud }\end{array}$ & 235 \\
\hline & c. Kitchen & 29.3 & 66 & $\begin{array}{l}\text { Not } \\
\text { loud }\end{array}$ & 665 \\
\hline \multirow[t]{4}{*}{3} & \multicolumn{5}{|c|}{ KM Tanto } \\
\hline & a. Engine room & 28.8 & 912 & Loud & 84 \\
\hline & b. Office & 28.5 & 62.2 & $\begin{array}{l}\text { Not } \\
\text { loud }\end{array}$ & 168 \\
\hline & c. Kitchen & 29.0 & 59.8 & $\begin{array}{l}\text { Not } \\
\text { loud }\end{array}$ & 270 \\
\hline \multirow[t]{4}{*}{4} & \multicolumn{5}{|c|}{ KM Red Rock } \\
\hline & a. Engine room & 31.5 & 90 & Loud & 241 \\
\hline & b. Office & 24.7 & 59.2 & $\begin{array}{l}\text { Not } \\
\text { loud }\end{array}$ & 170 \\
\hline & c. Kitchen & 26.9 & 65.6 & $\begin{array}{l}\text { Not } \\
\text { loud }\end{array}$ & 192 \\
\hline
\end{tabular}

Results of Heat Stress Apparatus examination showed that WGBT in the workplace was between $22.1^{\circ} \mathrm{C}$ and $31.1^{\circ} \mathrm{C}$. The range was not that good because optimum WGBT was between $24^{\circ} \mathrm{C}-28^{\circ} \mathrm{C}$. Rooms with high temperatures were mostly engine rooms. That condition made workload heavier and increased the number of calories needed to work. Exposure of high temperature above optimum WGBT level should be controlled.

Noise measurement with Sound Level Meter showed that noise level in the workplace was between $53 \mathrm{~dB}$ and $91.2 \mathrm{~dB}$. High noise exposures were mostly in engine rooms which were above NAB $85 \mathrm{~dB}$, as assigned by PerMenakertrans. Noise exposure above TLV can cause hearing loss and occupational diseases related to hearing.

Result of dust exposure measurement with HDVS showed that dust exposure in the workplace was $0.000022-.000203 \mathrm{mg} / \mathrm{m}^{3}$ which was still in safe level. Dust TLV is the level which provides comfortable workplace condition which is $10 \mathrm{mg} / \mathrm{m}^{3}$. Dust particles of $0.1-10 \mathrm{p} . \mathrm{m}$ can harm health because such particles stay in the air for a long time, are inhaled by workers and result in respiratory diseases.

Lighting in the workplace was 75-665 Lux. Low level of lighting was generally in engine rooms ( $<100$ Lux).

Examination to detect occupational diseases was done through hearing acuity examination with Audiometer and lung examination with Autospirometer. The result of examination showed that $83 \%$ of the respondents suffered occupational diseases. The highest risk happened to ship crews $(60 \%)$ and to KKP workers $(23 \%)$. The risk could be seen from the decrease of hearing acuity and lung function of harbor workers.

Implementation of PPE is an effort to prevent occupational diseases. The percentage of compliance with PPE was still low. Only $51 \%$ of the workers were at risk of occupational diseases and used PPE. Implementation of PPE is important for prevention.

\section{DISCUSSION}

Workplace comfort depends on ambient temperature and relative humidity in the workplace. If the two factors increase, workplace discomforts can possibly happen. An increase of the two factors can promote health problems, such as sweating, dehydration, salt loss, loss of perceptual and motor performance, heat exhaustion, loss of ability to work intensively due to heat exhaustion, increased accident risk, even heat stroke and death. ${ }^{[5]}{ }^{[6]}$ Exposure above normal temperature $24^{\circ} \mathrm{C}-28^{\circ} \mathrm{C}$ can cause health problems for workers. Exposure above $28^{\circ} \mathrm{C}$ can cause exertional heat illness (EHI). ${ }^{[7]}$ Extreme temperature exposure needs to be controlled by providing guides to be applied in workplaces. Workplace and health periodic examination should be conducted to prevent extreme heat stress. ${ }^{[8]}$

Noise exposure increases the risk of occupational injury in the workplace. The higher noise exposure is in the workplace, the higher risk of occupational injury and disease possibly occurring. ${ }^{[9]}$ Noise exposure occurs more often in developing countries than that in developed countries. This possibly happens because of supervision factor and non-compliance with PPE. Noise exposure control in workplaces through compliance with PPE should be implemented. This is because with every $1 \mathrm{~dB}$ increase above TLV, hearing loss possibility will be higher. ${ }^{[10]}$ If workers have already suffered hearing loss, they should be supported with hearing aids and be moved to work areas where there is no high noise exposure. Noise control can be implemented through periodic hearing acuity measurement, earmuff use, earplug and noise source control. ${ }^{[11]}$ 
Dust exposure is related to occupational rhinitis cases. Dust can also cause respiratory problems when the exposure is above TLV. The result of this research was in line with a research in Benin which stated that dust exposure in workplaces resulted in a higher number of workers with respiratory problems than that of workplaces without dust exposure. ${ }^{[12][13]}$

The lighting level should be improved so that workers' performance in engine rooms improves. Good lighting, air circulation and sunlight availability can have a positive effect on workers. The lack of those factors can increase cortisol level and decrease melatonin level during the night. This causes depressive symptoms and bad quality of sleep. ${ }^{[14][15]}$

The use of PPE was an attempt to decrease and to protect workers from occupational injuries and diseases. Implementation of PPE and occupational injuries and diseases had a positive correlation. Implementation of PPE is needed to protect workers from workplace hazards. ${ }^{[16]}$

OSHA ${ }^{[17]}$ stated that every worker has to use PPE properly. OSHA also requires workers to have training in implementation of PPE. The training will improve workers' knowledge of how to maintain PPE well and will train responsiveness to inform supervisors when PPE is incomplete or in need of any replacement.

Improving interpersonal support and social norm also can be an effort to improve compliance with PPE in workplaces. ${ }^{[18]}$ Good PPE implementation can decrease the risk of occupational injury and disease and also decrease the cost of occupational injury and disease ${ }^{[19]}$. PPE used by workers should be based on workers' need and risk in workplaces. ${ }^{[20]}$

\section{V.CONCLUSION}

The risk of occupational disease (OC) from agent factor was non-compliance with PPE. The host should engage more to decrease the risk, because agent (noise, heat) in the form of workplace hazard is difficult to be controlled as the agent comes from engines and transportation in the harbor. It was recommended that case detection of the possibility of increase in occupational disease cases should be conducted in the harbor community.

\section{Acknowledgement}

Thank you very much to
Department of Occupational and Health Safety, Faculty of Public Health, Universitas Airlangga and Port Health Office, Surabaya.

\section{REFERENCES}

[1] World Health Organization. "Alert, response, and capacity building under the International Health Regulations (IHR)". Accessed June 23, 2014 http://www. who. int/ihr/about/en/. .

[2] Wang, Y, S. Zhan, Y. Liu, and Y. Occupational hazards to health of port workers. International Journal of Occupational Safety and Ergonomics, 19 (July 2016): 1-5

[3] Amponsah-Tawiah, K, S. Leka, A. Jain, D. Hollis, and T.Cox. The impact of physical and psychosocial risks on employee well-being and quality of life: The case of the mining industry in Ghana. Safety Science. 65 (June 2014):28-35 .

[4] Takala, J, P. Hämäläinen, K.L. Saarela, L.Y. Yun, K. Manickam, T.W. Jin, P. Heng, C. Tjong, L.G. Kheng, S. Lim, and G.S. Lin. Global estimates of the burden of injury and illness at work in 2012. Journal of Occupational and Environmental Hygiene. 11, no. 5 (May 2014): 326-327.

[5] Parsons, K. Human Thermal Environments: The Effects of Hot, Moderate and Cold Environments on Human Health, Comfort and Performance. 2nd ed. New York: CRC Press, 2002.

[6] Srinivasan, K, K.N. Maruthy, V. Venugopal, and P. Ramaswamy. Research in occupational heat stress in India: Challenges and opportunities. Indian journal of Occupational and Environmental Medicine. 20, no.2 (May 2016):73.

[7] Garzon-Villalba, X.P., A. Mbah, Y. Wu, M. Hiles, H. Moore, S.W. Schwartz, and T.E. Bernard. Exertional heat illness and acute injury related to ambient wet bulb globe temperature. American Journal of Industrial Medicine, 59, no. 12 (Dec2016):1169-1176.

[8] Lucas, R.A., Y. Epstein, and T. Kjellstrom. Excessive occupational heat exposure: a significant ergonomic challenge and health risk for current and future workers. Extreme Physiology \& Medicine, 3, no.1. (July2014):14.

[9] Yoon, J.H., J.S. Hong, J. Roh C.N. Kim, and J.U.Won. Dose-response relationship between noise exposure and the risk of occupational injury. Noise \& Health, 17, no. 74 (Jan 2015):43.

[10] Girard, S.A., T. Leroux, M. Courteau, M. Picard, F. Turcotte, and O. Richer. Occupational noise exposure and noise-induced hearing loss are associated with workrelated injuries leading to admission to hospital. Injury Prevention, (Mar 2014).

[11] Lie, A., M. Skogstad, H.A. Johannessen, T. Tynes, I.S. Mehlum, K.C. Nordby, B. Engdahl, and K. Tambs. Occupational noise exposure and hearing: a systematic review. International Archives of Occupational and Environmental Health, 89, no. 3 (Apr 2016):351-372.

[12] Hinson, A.V., V.K. Lokossou, V. Schlünssen, G. Agodokpessi, T. Sigsgaard, and B. Fayomi. Cotton Dust Exposure and Respiratory Disorders among Textile Workers at a Textile Company in the Southern Part of Benin. International Journal of Environmental Research and Public Health, 13, no. 9 (Sept 2016):895.

[13] Hamzah, N.A., S.B. Tamrin, and N.H. Ismail. Metal dust exposure and respiratory health of male steel workers in Terengganu, Malaysia. Iranian Journal of Public Health, 43, no.3(Jan 2014):154.

[14] Harb, F., M.P. Hidalgo, and B. Martau. Lack of exposure to natural light in the workspace is associated with 
physiological, sleep and depressive symptoms. Chronobiology International, 32, no.3 (Mar 2015):368375 .

[15] Boubekri, M., I.N. Cheung, K.J. Reid, C.H. Wang , and P.C. Zee. Impact of windows and daylight exposure on overall health and sleep quality of office workers: a casecontrol pilot study. Journal of Clinical Sleep Medicine: JCSM: Official Publication of the American Academy of Sleep Medicine, 10, no. 6 (Jun 2014):603

[16] HSE. Personal Protective Equipment at work. Health and Safety Executive. 2013

[17] OSHA. Personal Protective Equipment. 2015

[18] Lu, L., L. Shi, L. Han, and L. Ling. Individual and organizational factors associated with the use of personal protective equipment by Chinese migrant workers exposed to organic solvents. Safety Science, 76 (July 2015):168-174

[19] Buica, G., A.E. Antonov, C. Beiu, D. Pasculescu , and D. Remus. Occupational health and safety management in construction sector-the cost of work accidents. Calitatea, 18, no. S1 (Jan 2017):35.

[20] Verbeek, J.H., S. Ijaz, C. Mischke, J.H. Ruotsalainen, E. Mäkelä, K. Neuvonen, E.B. Edmond, R. Sauni, F.S. Kilinc Balci, and R.C. Mihalache. Personal protective equipment for preventing highly infectious diseases due to exposure to contaminated body fluids in healthcare staff. The Cochrane Library (Jan 2016). 